\title{
Delayed Hemolytic Transfusion Reaction in Sickle Cell Disease
}

\author{
Narcisse Eleng a* \\ Service de Pédiatrie, Centre hospitalier de Cayenne,Cay enne cedex, Guy ane française \\ *Corresponding author: elengafr@y ahoo.fr
}

Received December 31, 2012; Revised May 16, 2013; Accepted May 17, 2013

\begin{abstract}
Patients with sickle cell disease frequently require red blood cell transfusions. However, transfusions can cause delayed hemolytic transfusion reaction (DHTR), a serious and potentially life-threatening complication of alloimmunization that results in hemolysis of transfused as well as patients' own red cells. Although we are beginning to understand some of the pathophysiology and risk factors associated with alloimmunization, optimal management of DHTR in this patient population is still under debate. Here, I will review the clinical features, pathophysiology, laboratory evaluation, current strategies for management and prevention of DHTRs. Given that DHTRs are associated with massive hemolysis, it is recommended that all patients with sickle cell disease receiving transfusions are carefully and systematically monitored after each transfusion.
\end{abstract}

\section{Keywords: delayed hemolytic transfusion reaction, sickle cell disease}

\section{Background}

Red blood cell (RBC) transfusion is often used for treatment and management of sickle cell disease (SCD). The purpose of RBC transfusion is to increase oxygen distribution to the tissues and/or to replace the rig id sickleshaped RBCs with healthy deformable RBCs. However, because of the frequency of transfusions in their life-time, patients with SCD become exposed to RBCs alloantigens of donor units, making them more likely to produce alloantibodies, which in turn puts them at risk for delayed hemolytic transfusion reactions (DHTRs). In addition, exchange transfusions, which are often used for these patients, may increase the risk of DHTR. This is because there is increased red cell utilization with exchange transfusions, with more exposure to foreign erythrocyte antigens and increased volume of transfused erythrocytes susceptible to hemolysis during DHTR. A llo immunization in SCD has a reported incidence of $20 \%$ to $50 \%$ [1,2]. Red cell alloimmunization is frequent because of the antigen disparities between patients of African descent and donors of European ancestry $[3,4,5]$.

Table 1. Pathophysiological mechanisms of DHTR 1- Differences in erythrocyte antigens between blood donors of European descent and patients of African descent (Yazdanbakhsh et al. 2012)

2-Interaction and destruction of the patient's own cells (HbSS/reticulocytes) and transfused cells by activated macrophages (Platt et al. 2000)

3- Destruction of antigen negative RBCs during immune hemolysis of antigen positive RBCs « bystander hemolysis » (King et al, 1997) 4- Increased RBC exposure of phosphatidylserine (Lang et al, 2005) 5- Acceleration of eryptosis( Petz et al, 1997)

6- Association of alloimmunization with particular HLA subtypes (Hoppe et al. 2009)

The DHTR syndrome is a serious and potentially lifethreatening complication of alloimmunization, which has a reported incidence of $4 \%$ to $11 \%$ [1,3]. It is characterized by recurrence of disease complications such as recipient RBCs destruction. In some cases, no detectable antibody is present. DHTR is associated with a significant morbidity or mortality. The pathophysiology of this syndrome remains unclear; especially when there is no detectable antibody. Accelerated apoptosis of donor RBCs has been recently suggested as a potential mechanis $m$ of recipient $\mathrm{RBC}$ destruction during DHTR $[6,7,8]$.

Table 2. Components of delayed haemolytic transfusion reaction in sickle cell disease*

\begin{tabular}{|l|}
\hline Clinical feat ures \\
\hline $\begin{array}{l}\text { Fever and sickle pain: symptoms that could have been easily } \\
\text { misleading for a simple VOC }\end{array}$ \\
\hline $\begin{array}{l}\text { A fall in absolute reticulocyte count (decrease from patient's usual } \\
\text { base level) }\end{array}$ \\
\hline $\begin{array}{l}\text { Development of severe anemia after transfusion: post-transfusion } \\
\text { hemoglobin (Hb) level lower than the pretransfusion value }\end{array}$ \\
\hline $\begin{array}{l}\text { Evidence of hemolysis (hemoglobinuria, hyperbilirubinemia and } \\
\text { raised lactate dehydrogenase(LDH) }\end{array}$ \\
\hline $\begin{array}{l}\text { A fall in absolute reticulocyte count (decrease from patient's usual } \\
\text { base level) }\end{array}$ \\
\hline Recovery manifested by a rise in Hb and reticulocyte count \\
\hline Diagnosis \\
\hline In many cases, the antibody screening remains negative \\
\hline $\begin{array}{l}\text { Hemoglobin electrophoresis: total or near total destruction of donor } \\
\text { erythrocytes, indicated by a lack of hemoglobin A }\end{array}$ \\
\hline $\begin{array}{l}\text { The increase in HbS percentages indicating destruction of the } \\
\text { transfused RBCs confirms the diagnosis of DHTR }\end{array}$ \\
\hline Clinical management \\
\hline $\begin{array}{l}\text { Standard treatment of DHTR includes hospitalization, hydration, } \\
\text { administration of intravenous immunoglobulins, corticosteroids or } \\
\text { both and recently Rituximab }\end{array}$ \\
\hline $\begin{array}{l}\text { Hydroxyurea, because of its my elosuppressive effects could be } \\
\text { added to the therapeutic strategy for reducing granulocytosis }\end{array}$ \\
*Adapted from Petz, L.D., Calhoun, L., Shulman, I.A., Johnson, C. and \\
Herron, R.M. The sickle cell hemolytictransfusion reaction syndrome. \\
Transfusion 1997; 37:382-392
\end{tabular}


Signs and symptoms of DHTR are quite similar to those of vaso-occlusive crisis (VOC) in patients with sickle cell disease $[9,10]$. This makes the diagnosis of DHTR and appropriate therapeutic decisions still a challenging issue to clinicians in charge of patients affected by DHTR.

In this review, we present a synthesis of the current understanding of the pathophysiology of alloimmunization, as well as the clinical features, diagnosis and management strategies of DHTR in SCD (Table 1 and Table 2).

\section{Pathophysiology}

The pathophysiology of DHTR in SCD patients has not been completely elucidated. Classically, DHTR is ascribed to a reaction between anti-RBC antibodies produced by the recipient and antigens expressed by the donor RBCs $[6,7,8,9,10]$. It remains unclear why some patients develop strong alloantibody responses following initial RBC transfusions, while others do not despite multiple transfusions. However, anti-RBC antibodies are often undetectable in SCD patients with DHTR [1,4,7]. The high proportion of DHTR cases without identifiable antibodies suggests that multiple factors are involved in the pathophysiology of this life-threatening complication.

1- Differences in erythrocyte antigens between blood donors of European descent and patients of African descent.

It is generally accepted that the high rate of alloimmunization in SCD patients is mainly due to the polymorphic differences in immunologic RBC antigens between the predominantly white general blood donors and patients of predominantly African descent $[11,12]$. In the countries, where donors and patients are racially more homogeneous, low rates of alloimmunization have been reported $[13,14]$. These reports support the idea that racial antigenic differences account for increased allo immun ization rates.

Antigenic differences between donors and SCD patients could be represented at three levels of complexity:

- First, there is a substantial difference in the prevalence of some common but highly immunogenic RBC antigens between donors and transfusion recipients. The following blood groups: $\mathrm{C}$ and $\mathrm{E}$ in the Rhesus (RH), $\mathrm{K}$ in the Kell (KEL), Fy ${ }^{\mathrm{a}}$ in the Duffy (FY), $\mathrm{Jk}^{\mathrm{b}}$ in the Kidd (JK), and $\mathrm{S}$ in the MNS are more frequently encountered in whites than in black African descents.

- Second, other antigens are more immunogenic in blacks: RH32 encoded by the RN haplotype, DAK encoded by DIIIa, DOL, and RN $[15,16], \mathrm{Js}^{\mathrm{a}}$ and $\mathrm{Co}^{\mathrm{b}}$ antigens $[17,18]$.

- Third, alloimmunization in SCD patients is also possible when the recipient lacks an antigen that is expressed in almost all donor RBCs. These main concerned blood groups are RH (the absence of $\mathrm{Hs}, \mathrm{HrB}$, or RH46), KEL (the absence of Jsb) and of MNS (absence of U) [19].

Partial antigens are frequently encountered in AfroCarribean patients. These patients make alloantibodies when exposed to the complete antigen through transfusion or pregnancy.

2- The theory of apoptosis

According to one hypothesis, stored donor RBCs may experience accelerated eryptosis in the bloodstream of SCD patients, with extemalization of the phosphatidylserine (PS) membrane at the outer surface of the cell [6]. The exposure of PS in RBC has recently been reported to be significantly increased following the incubation of donor RBC with pre-transfusion plasma samples from SCD patients who develop DHTR compared to other SCD patients who do not develop this complication [8]. Furthermore, the exposure of PS in RBC progressively increased in patients with DHTR, particularly when donor erythrocytes were completely destroyed. As PS exposure is a signal for apoptosis, this increases the suicidal death of RBC. PS exposure may contribute to the increased hemolysis observed during DHTR. The role of PS in RBC adhesion to endothelium may also, at least in part, explain the severe pain episodes observed during DHTR. RBCs may be rapidly destroyed by macrophages, which are probably activated. By performing a hemoglobin electrophoresis, it is easy to show that donor RBCs are often completely destroyed [20]. The reason for this is obvious when new antibodies directed against the transfused units are observed. However, alloantibodies may not be detected at the time of the DHTR, may become detected later, or may never be detected [21]. The worsening anemia probably represents a combination of hemolysis of transfused cells, hyperhemolysis related to the immunologic response, and suppression of erythropoesis.

The so-called "bystander hemolysis" may be a major mechanis $m$ in DHTR in SCD. In addition to alloimmune and autoimmune RBC lysis, a third category of immune destruction of blood cells should be recognized [22]. This additional immunologic response occurs when RDC are injured by immunologic reactions in which the RBC act as "innocent bystanders." Bystander hemolysis may be defined as the destruction of antigen-negative RBCs during immune hemolys is of antigen-positive RBCs. King et al. suggested the bystander haemolys is mechanism [23]. One mechanism by which an immune response to an exogenous antigen leads to the destruction of autologous $\mathrm{RBC}$ is the temporary development of autoantibodies. This is actually an alloimmune reaction which results in a temporary state of "pseudo"-autoimmunity. Although originally described as a type of hemolysis of autologous cells, the concept of bystander immune cytolysis has been extended to include other instances in which immune destruction of cells is caused by antibody that is not developed in response to intrinsic antigens on the cell being lysed. Bystander hemolysis during DHTR may occur following activation of complement as a result of the reaction of alloantibodies with transfused RBCs or other antibody reactions with transfused foreign antigens, leading to the attachment of activated complement components to autologous RBCs. The delayed form of DHTR represents a typical example of the bystander hemolytic mechanism [24]. The suppression of erythropoeis is that accompanies transfusion may also contribute to the increased anemia observed following a DHTR. Marked reticulocytopenia is not always a feature of DHTR. As patients with SCD have a shortened RBC survival, suppression of erythropoiesis has a profound effect on hemoglobin concentration compared to patients with normal red cell lifespan.

3- The theory of inflammation

SCD has been postulated to be a chronic inflammatory disease. One possibility is that a non-clinically significant 
antibody may become significant when the donor RBCs undergo accelerated senescence in the bloodstream. This mechanism which worsens anaemia following $\mathrm{RBC}$ transfusion still remains controversial. Based on the finding of erythroid hyperplasia on a bone marrow aspirate during DHTR, a more recent case report suggests that the observed reticulocytopenia is not due to suppression of erythropoies is, but rather is likely related to peripheral RBC consumption. While no experimental data were provided, a few authors postulated that this could be related to enhanced macrophages activation [25,26,27].

4- The murine models of DHTR

The murine models of DHTR have strongly demonstrated that SCD is characterized by chronic inflammation. It is possible that inflammation may play a role in the high rate of alloimmunization observed in these patients. However, there are, to date, no published data in SCD patients [28].

5- The DHTR and HLA types.

Associations of HLA types with alloimmunization in SCD patients with numerous transfusions have been described [29,30]. More recently, a case-controlled study demonstrated associations of alloimmunization with particular HLA subtypes [31]. The HLA-DRB1*1503 allele was associated with an increased risk of alloimmunization [26,28,32], while the HLA-DRB1*0901 allele appeared to confer protection from developing alloantibodies.

Specific risk factors for DHTR in patients without detectable antibodies are unknown. Consequently, patients at risk for a first or recurrent episode of DHTR cannot be identified.

\section{Clinical Features}

The clinical features of DHTR include [1,20,23,25,3335]:

Fever and sickle pain: symptoms that could have been easily mistaken for a simple VOC in the SCD population.

Development of severe anemia after transfusion: posttransfusion hemoglobin $(\mathrm{Hb})$ level lower than the pretransfusion value.

Evidence of hemolys is (hemoglobinuria, hyperbilirubinemia and raised lactate dehydrogenase $(\mathrm{LDH})$.

A fall in absolute reticulocyte count (decrease from patient's usual base level).

Recovery manifested by a rise in $\mathrm{Hb}$ and reticulocyte count.

Additional transfusion may exacerbate ongoing hemolysis (may lead to protracted course or even death).

Further classified into -acute(in the acute form of DHTR, both autologous cells and transfused cells are destroyed in the absence of red cell alloantibodies).

-and delayed form (in the delayed form of DHTR, new RBC alloantibodies are often identified in post-transfusion patients' samples).

DHTR may recur following subsequent transfusion (although this is extremely rare).

\section{Diagnosis}

The diagnosis of a DHTR is often difficult and delayed. Clinicians in charge of SCD patients should sufficiently be sensitized and informed on this complication. The initial symptoms of DHTR are often complex and mimic other complications of SCD such as severe VOC. Hemolysis is often present in these patients. Reticulocytopenia may mimic aplastic crisis. DHTR may be more common than is generally recognized and should be considered when a patient has a sickle cell pain crisis approximately 5-15 days after receiving a transfusion. Because of difficulties in getting compatible blood for future transfusions, it is important to identify the responsible red cell antigen at the time of the DHTR.

It is important that DHTR be included in the differential diagnosis of severe acute pain episodes and decreasing $\mathrm{Hb}$ (often lower than it was at the time of orig inal transfusion), following a RBC transfusion in a patient with SCD.

Laboratory testing should include a complete blood count with reticulocyte count, an antibody screening (indirect antiglobulin test and direct antiglobulin test) to detect new RBC alloantibodies and/or autoantibodies and a Hemoglobin electrophoresis. Blood chemistry testing should include a serum bilirubin (total and indirect) and $\mathrm{LDH}$ to estimate for increased hemolysis, and a urine sample to measure hemoglobinuria [18].

Inability to identify a new antibody does not exclude the diagnosis of a DHTR, and in many cases, the antibody screening remains negative. A hemoglobin electrophores is is also helpful in establishing the diagnosis of a DHTR. Hemoglobin electrophoresis often demonstrates total or near total destruction of donor erythrocytes, indicated by a lack of hemoglobin A in the specimen [25-38]. The increase in $\mathrm{HbS}$ percentages indicating destruction of the transfused RBCs confirms the diagnosis of DHTR $[25,34,36,37,38]$.

\section{Treatement}

Although DHTR is a serious and potentially lifethreatening complication in children with $\mathrm{SCD}$, a standard evidence-based approach to therapy has not yet been established. Standard treatment of DHTR includes hospitalization, hydration, administration of intravenous immunoglobulins, corticosteroids or both and recently Rituximab [3,5,9,39-57]. However, no randomized controlled trials have been carried out to as sess treatments for SCD patients with DHTR. Continuation of blood transfusion may be lethal, as this can further exacerbate hemolysis. For those who develop severe acute hemolys is, Corticosteroids (CS) are believed to be acceptable therapeutic options, because of their potent immunosuppressive properties [12,51]. In SCD patients however, there is controversy concerning the effects of steroids. The high frequency of rebound attacks and readmission in SCD children treated with dexamethasone for painful crises or moderate acute chest syndromes argues against the use of CS in these patients [51,52].

In addition, severe pain episodes and stroke were reported to occur in four SCD patients after ad ministration of steroids for rheumatoid arthritis and autoimmune hepatitis [55,56,57]. More recently, long-term administration of steroids for the treatment of auto-immune diseases in SCD children was reported to be poorly tolerated with worsening of the course of SCD [56]. The bas is for the association between CS and the neurological complications in children is speculative [3]. CS often increase blood pressure. However, in severe 
hemolysis, when corticosteroids become necessary, transfusion therapy designed to maintain the hemoglobin S percentage below $30 \%$, should be considered. Such a protective effect has been recently reported for SCD patients treated with both corticosteroids and transfusion therapy for severe acute chest syndrome [56]. A recent study suggested that hydroxyurea, because of its myelosuppressive effects, could be added to the therapeutic strategy for reducing granulocytosis [3,58]. Few authors have also used high doses of erythropoietin, although baseline levels are likely to be elevated in patients with normal renal function. Pain episodes and other complications associated with DHTR should be treated as required. Immune-modulating medications provide an exciting possibility for new modalities of DHTR prevention. Although clinical trials are lacking, a case report presented a patient with three prior episodes of DHTR for whom rituximab, a monoclonal antibody that targets B cells by binding with CD20, allowed successful transfusion [49]. This will likely be an active area of research in upcoming years.

Finally, patients should be educated about DHTR, providing them with a letter (or card) that explains this complication and listing any known alloantibodies, so that medical providers who are otherwise not familiar with the patient's medical history avoid unnecessary transfusions.

\section{Conclusion}

Since DHTR frequently mimics other manifestations of SCD and since post-transfusion screening tests are usually negative, its diagnosis may be underestimated in SCD patients. Patients in whom the diagnosis of DHTR is missed may receive repeated transfusions, which may contribute to the mortality as sociated with SCD. The high proportion of DHTR cases without identifiable antibodies suggests that different factors are involved in the physiopathology of this potentially life-threatening complication. Among these factors, inflammation may play a substantial role. Further research on genetic associations with DHTR will likely provide considerable help in elucidating risk factors, and perhaps the pathogenesis, of this syndrome. Minimizing RBC transfusion and the use of more extensive phenotypic matching of blood, particularly the Rh and Kell blood group systems, when transfusion is required are essential to decrease the risk for alloimmunization.

The optimal treatment of DHTR is still not defined. However, many patients appear to respond to treatment with high-dose steroids, with or without intravenous immunoglobulin. More studies are needed to define the optimal treatment of this life threatening complication in SCD.

\section{Acknowledgements}

The author thanks Dr Karina Yazdanbakhsh (New York Blood Center, USA) for her comments and corrections on the manuscript.

\section{References}

[1] Talano, J.A., Hillery, C.A., Gottschall, J.L., Baylerian, D.M. and Scott, J.P., Delayed hemolytic transfusion reaction/hyperhemolysis syndrome in children with sickle cell disease. Pediatrics. 2003 Jun; 111(6 Pt 1): e661-5.

[2] Vichinsky EP. Current issues with blood transfusions in sickle cell disease. Semin Hematol 2001; 38(1):14-22.

[3] Elenga, N., Mialou, V., Kebaïli, K., Galambrun, C., Bertrand, Y. and Pondarre, C., Severe neurologic complication after delayed hemolytic transfusion reaction in 2 children with sickle cell anemia: significant diagnosis and therapeutic challenges. $J$ Pediatr Hematol Oncol. 2008 Dec; 30(12):928-30.

[4] de Montalembert, M., Dumont, M.D., Heilbronner, C., Brousse, V., Charrara, O., Pellegrino, B., Piguet, C., Soussan, V.and Noizat-Pirenne, F., Delayed hemolytic transfusion reaction in children with sickle cell disease. Haematologica. 2011 Jun; 96(6):801-7.

[5] Noizat-Pirenne, F. and Tournamille, C., Relevance of RH variants in transfusion of sickle cell patients.Transfus Clin Biol. 2011 Dec; 18(5-6):527-35. Epub 2011 Oct 22.

[6] Chadebech, P., Habibi, A., Nzouakou, R., Bachir, D., MeunierCostes, N., Bonin, P., Rodet, M., Chami, B., Galacteros, F., Bierling, P. and Noizat-Pirenne, F., Delayed hemolytic transfusion reaction in sickle cell disease patients: evidence of an emerging syndrome with suicidal red blood cell death.Transfusion. 2009 Sep; 49(9):1785-92.

[7] Aygun, B., Padmanabhan, S., Paley, C. and Chandrasekaran, V., Clinical significance of RBC alloantibodies and autoantibodies in sickle cell patients who received transfusions.Transfusion. 2002 Jan;42(1): 37-43.

[8] King, K.E., Shirey, R.S., Lankiewicz, M.W., Young-Ramsaran, J. and Ness, P.M., Delayed hemolytic transfusion reactions in sickle cell disease: Simultaneous destruction of recipients' red cells. Transfusion 1997; 37(4):376-381.

[9] Diamond, W.J., Brown, F.L. Jr., Bitterman, P., Klein, H.G., Davey, R.J. and Winslow, R.M., Delayed hemolytic transfusion reaction presenting as sickle-cell crisis. Ann Intem Med. 1980 Aug; 93(2): $231-4$.

[10] Fabron, A. Jr., Moreira, G. Jr. and Bordin, J.O., Delayed hemolytic transfusion reaction presenting as a painful crisis in a patient with sickle cell anemia. Sao Paulo Med J. 1999 Jan 7; 117(1):38-9.

[11] Yazdanbakhsh K, Ware RE, Noizat-Pirenne F. Red blood cell alloimmunization in sickle cell disease: pathophysiology, risk factors, and transfusion management. Blood. 2012 Jul 19; 120(3):528-37.

[12] Noizat-Pirenne F. Relevance of blood groups in transfusion of sickle cell disease patients.C R Biol. 2013 Mar;336(3):152-8.

[13] Natukunda B., Schonewille H., Ndugwa C, Brand A. Red blood cell alloimmunization in sickle cell disease patients in Uganda. Transfusion 2010; 50(1):20-25.

[14] Olujohungbe A., Hambleton I., Stephens L., Serjeant B., Serjeant G. Red cell antibodies in patients with homozygous sickle cell disease: a comparison of patients in Jamaica and the United Kingdom. Br J Haematol 2001; 113(3):661-665.

[15] Rouillac C., Gane P., Cartron J., Le Pennec P.Y., Cartron J.P., Colin Y. Molecular basis of the altered antigenic expression of $\mathrm{RhD}$ in weak $\mathrm{D}(\mathrm{Du})$ and RhC/e in RN phenotypes. Blood 1996; 87(11):4853-4861.

[16] Reid M.E., Storry J.R, Sausais L., Tossas E., Rios M., Hue-Roye K., Gloster E.S., Miller S.T., Wolf C., Lomas-Francis C. DAK, a new low-incidence antigen in the $\mathrm{Rh}$ blood group system. Transfusion 2003; 43(10):1394-1397.

[17] Anderson R.R., Sosler S.D., Kovach J., DeChristopher P.J. Delayed hemolytic transfusion reaction due to anti-Js(a) in an alloimmunized patient with a sickle cell syndrome. Am J Clin Pathol 1997; 108(6):658-661.

[18] Scheunemann LP, Ataga KI. Delayed hemolytic transfusion reaction in sickle cell disease. Am J Med Sci. 2010 Mar;339(3):266-9.

[19] Noizat-Pirenne F. [Immunohematologic characteristics in the Afro-Caribbean population: consequences for transfusion safety]. Transfus Clin Biol 2003; 10(3):185-191.

[20] Petz, L.D., Calhoun, L., Shulman, I.A., Johnson, C., Herron, R.M The sickle cell hemolytic transfusion reaction syndrome. Transfusion 1997; 37:382-392

[21] Lang, K.S., Lang, P.A., Bauer, C., Duranton, C., Wieder, T., Huber, S.M. and Lang, F., Mechanisms of suicidal erythrocyte death. Cell Physiol Biochem 2005; 15:195-202.

[22] Petz LD. Bystander immune cytolysis Transfus Med Rev. 2006 Apr;20(2):110-40. 
[23] King K.E., Shirey R.S., Lankiewicz M.W., Young-Ramsaran J., Ness P.M. Delayed hemolytic transfusion reactions in sickle cell disease: simultaneous destruction of recipients' red cells.Transfusion. 1997 Apr;37(4): 376-81.

[24] Darabi K., Dzik S. Hyperhaemolysis syndrome in anaemia of chronic disease. Transfusion 45, 1930-1933 (2005).

[25] Win, N., Doughty, H., Telfer, P., Wild, B.J. and Pearson, T.C., Hyperhemolytic transfusion reaction in sickle cell disease. Transfusion. 2001; 41(3): 323-8.

[26] Platt O.S., Sickle cell anemia as an inflammatory disease. J Clin Invest 2000; 106:337-338.

[27] Ni Choileain N. and Redmond H.P., Cell response to surgery. Arch Surg. 2006; 141(11):1132-40.

[28] Zimring J.C. and Hendrickson J.E., The role of inflammation in alloimmunization to antigens on transfusedred blood cells. Curr Opin Hematol 2008; 15:631-635.

[29] 29-Alarif L., Castro O., Ofosu M., Dunston G., Scott R.B. HLAB35 is associated with red cell alloimmunization in sickle cell disease. Clin Immunol Immunopathol 1986; 8: 178-183.

[30] Reisner E.G., Kostyu D.D., Phillip G., Walker C., Dawson D.V. Alloantibody responses in multiply transfused sickle cell patients. Tissue Antigens 1987; 30:161-166.

[31] Hoppe C., Klitz W., Vichinsky E., Styles L. HLA type and risk of alloimmunization in sickle cell disease. Am J Hematol 2009; 84: 462-464.

[32] Hebbel R.P., Osarogiagbon R., Kaul D. The endothelial biology of sickle cell disease: Inflammation and a chronic vasculopathy. Microcirculation 2004; 11: 129-151.

[33] Cullis J.O., Win N., Dudley J.M., Kaye T. Post transfusion hyperhaemolysis in a patient with sickle cell disease: use of steroids and intravenous immunoglobulin to prevent further red cell destruction. Vox Sang.4,355-357 (1995).

[34] Win N., Tullie Y., Needs M., Chen P.E., Okpala I. Use of intravenous immunoglobulin and intravenous methylprednisolone in hyperhaemolysis syndrome in sickle cell disease. Haematology 9, 433-436 (2004).

[35] Win N., New H., Lee E., de la Fuente J. Hyperhemolysis syndrome in sickle cell disease: case report (recurrent episode) and literat ure review. Transfusion48, 1231-1238 (2008).

[36] Reeves, W.B. and Ballas, S.K., Delayed hemolytic transfusion reaction in sickle cell anemia. Transfusion. 1980 Jul-Aug; 20(4): 477.

[37] Natukunda B., Schonewille H., Ndugwa C., a Brand A. Red blood cell alloimmunization in sickle cell disease patients in Uganda. Transfusion. $2010 \mathrm{Jan} ; 50(1)$ : 20-5.

[38] Reyes M.A., Illoh O.C., Hyperhemolytic transfusion reaction attributable to anti-Fy3 in a patient with sickle cell disease.Immunohematology. 2008; 24(2): 45-51.

[39] Seeyave D., Desai N., Miller S., Rao S.P., Piecuch, S. Fatal delayed transfusion reaction in a sickle cell anemia patient with Serratia marcescens sepsis. J Natl Med Assoc. 2006 Oct;98(10): 1697-9.

[40] Kalyanaraman M., Heidemann S.M., Sarnaik A.P., Meert K.L., Sarnaik S.A. Anti-s antibody-associated delayed hemolytic transfusion reaction in patients with sickle cell anemia. J Pediatr Hematol Oncol. 1999 Jan-Feb; 21(1):70-3.

[41] Strupp A., Cash K., Uehlinger, J. Difficulties in identifying antibodies in the Dombrock blood group system in multiply alloimmunized patients.Transfusion. 1998 Nov-Dec; 38(11-12): 1022-5.

[42] Larson P.J., Lukas M.B., Friedman D.F., Manno C.S. Delayed hemolytic transfusion reaction due to anti-Go(a), an antibody against the low-prevalence Gonzales antigen. Am J Hematol. 1996 Dec;53(4): 248-50.

[43] Hillyer C.D., Hall J.M., Tiegerman K.O., Berkman E.M. Case report and review: alloimmunization, delayed hemolytic transfusion reaction, and clinically significant anti-Yt (a) in a patient with Beta-thalassemia/sickle cell anemia Immunohematology. 1991; 7(4): 102-6.

[44] Bowen D.T., Devenish A., Dalton J., Hewitt P.E. Delayed haemolytic transfusion reaction due to simult aneous appearance of anti-Fya and Anti-Fy5. Vox Sang. 1988; 55(1):35-6.

[45] Ballas S.K., Dignam C., Harris M., Marcolina M.J. A clinically significant anti-N in a patient whose red cells were negat ive for $\mathrm{N}$ and U antigens. Transfusion. 1985 Jul-August; 25(4): 377-80.

[46] Chan-Shu S.A. The second example of anti-Duffy5. Transfusion . 1980 May-Jun; 20(3): 358-60.

[47] Ohene-Frempong K. Indications for red cell transfusion in sickle cell disease. Sem in Hematol. 2001; 38(1 Suppl 1): 5-13.

[48] Hannema S.E., Brand A., van Meurs A., Smiers, F.J. Delayed hemolytic transfusion reaction with hyperhemolysis after first red blood celltransfusion in child with bet a-thalassemia: challenges in treatment. Transfusion. $2010 \mathrm{Feb}$;0(2):429-32.

[49] Noizat-Pirenne F., Bachir D., Chadebech P., Michel M., Plonquet A., Lecron J.C., Galactéros F., Bierling, P. Rituximab for prevention of delayed hemolytic transfusion reaction in sickle cell disease. Haematologica. 2007 Dec; 92(12):e132-5.

[50] Win N., Yeghen T., Needs M., Chen F.E., Okpala I. Use of intravenous immunoglobulin and intravenous methylprednisolone in hyperhaemolysis syndrome in sickle cell disease. Hematology. 2004 Oct-Dec; 9(5-6):433-6.

[51] Griffin T.C., McIntire D., Buchanan G.R. High-dose intravenous methylprednisolone therapy for pain in children and adolescents with sickle cell disease. N Engl J Med. 1994 Mar1 7; 330(11):7337.

[52] Bernini J.C., Rogers Z.R., Sandler E.S., Reisch J.S., Quinn C.T., Buchanan G.R. Beneficial effect of intravenous dexamethasone in children with mild to moderately severe acute chest syndrome complicat ing sickle cell disease. Blood. 1998 Nov 1;92(9):3082-9

[53] Nistala K., Murray K.J. Co-existent sickle cell disease and juvenile rheumatoid arthritis. Two cases with delayed diagnosis and severe destructive arthropathy. J Rheumatol. 2001 Sep; 28(9):2125-8.

[54] Gladman D.D., Bombardier C. Sickle cell crisis following intraarticular steroid therapy for rheumatoid arthritis. Arthritis Rheum. 1987 Sep; 30(9): 1065-8.

[55] Lykavieris P., Benichou J.J., Benkerrou M., Feriot J.P., Bernard O., Debray, D., Autoimmune liver disease in three children with sickle cell disease. J Pediatr Gastroenterol Nutr. 2006 Jan; 42(1): 104-8.

[56] Couillard S., Benkerrou M., Girot R., Brousse V., Ferster A. Bader-Meunier B.Steroid treatment in children with sickle-cell disease. Haematologica. 2007 Mar;92(3): 425-6.

[57] Isakoff M.S., Lillo J.A., Hagstrom J.N. A single-institution experience with treat ment of severe acute chest syndrome: lack of rebound pain with dexamethasone plus transfusion therapy. $J$ Pediatr Hematol Oncol. 2008 Apr; 30(4): 322-5.

[58] Jane A. Little, Vicki R. McGowan, Gregory J. Kato, Kristine S. Partovi, Jordan J. Feld, Irina Maric, Sabrina Martyr, James G. Taylor, VI, Roberto F. Machado, Theo Heller, Oswaldo Castro, Mark T. Gladwin. Combination Erythropoiet in-Hydroxyurea Therapy in Sickle Cell Disease: NIH experience and literature review. Haematologica. 2006 August; 91(8): 1076-1083. 